\title{
Sexual virtue on display I: the cults of pudicitia and honours for women
}

pulcherrima ... forma, maximum decus ... pudicitia

The loveliest form of beauty . . . the greatest adornment . . . pudicitia

(Seneca to his mother Helvia)

This book begins with a chapter about pudicitia as publicly celebrated and rewarded in Roman society. A striking aspect of pudicitia was its association with public and visual display by married women to the community, both through their appearance and demeanour and through their cultivation of pudicitia as a goddess. This first chapter explores the manifestation of pudicitia as a personified abstract virtue, a goddess described as playing an active role in the lives of ancient Romans, with her own shrines, cult statues and cult. It introduces key themes such as pudicitia's association with married women, public display, and the negotiation of the boundaries of social status. The chapter also exposes some of the tensions that lend this ideal of displaying pudicitia its frisson: its elusiveness; its dangerous proximity to, and strained relationship with, beauty; its fragility in the face of suspicion and gossip.

Pudicitia was a personal quality that needed to be displayed to and seen by others. Roman society demanded that a married woman (and particularly one involved in celebrating the cult of pudicitia) must strive to display the quality of pudicitia to the rest of the community in her person. Ideally pudicitia would shine forth from a married woman; it would turn heads when she walked down the street. As the philosopher Seneca writes to his mother Helvia, the most befitting ornament for a woman is pudicitia: "in you is seen the unique ornament, the most lovely kind of beauty, the greatest glory - pudicitia'. 'The most fortunate man in the

Sen. Dial. 12.I6.4. For further discussion of this passage see the end of this chapter, below. I here translate omamentum as 'ornament' and decus as 'glory'; at the head of the chapter and at the end of the chapter decus is translated as 'adornment'. This variation is an attempt to capture the range 
world' (according to the writer Valerius Maximus) ${ }^{2}$ has amongst his other blessings the ideal wife, whose supremacy is summed up thus: she is 'a wife who is conspicuous in her pudicitia and in her fecundity' (uxorem pudicitia et fecunditate conspicuam). ${ }^{3}$ It is not enough that a wife merely regulate her sexual behaviour in the accepted ways; it is required that her virtue in this area be conspicuous (conspicua) - plain for all to see, so remarkable as to attract attention. ${ }^{4}$ Ancient sources also tell us that women competed publicly among themselves in pudicitia, and that official honours were bestowed on those who were judged outstanding. Valerius Maximus describes a crown of pudicitia (corona pudicitiae) that was awarded publicly by the community to individuals pre-eminent in the quality, and several episodes in Roman history involve women honoured for their pudicitia. ${ }^{5}$ Throughout the empire, people declared the pudicitia of themselves and of their spouses on funerary epitaphs. ${ }^{6}$

These aspects of Roman sexual virtue - its need for publicity, its loud, attention-seeking nature - present a challenge. In this context, the (commonly offered) term 'modesty' simply will not do as a translation of pudicitia. ${ }^{7}$ It is also clear that pudicitia is something different from the repressive 'chastity' or 'continence' which those from cultures under the influence of puritan Christian sexual ethics might expect. ${ }^{8}$ A competition of sexual continence alone makes no sense, unless you expect almost every participant eventually to buckle under the strain and give in to the allure of adultery. One cannot compete in not doing something; there must be more to competitive pudicitia than this. ${ }^{9}$

of meanings of the Latin term, which embraces a sense of visual appeal, of honour and virtue, and of honorific award; the English term 'decoration', with its two senses of beautification and of (say) medals for military service, is etymologically related and has something of the same scope. The nuances of the word, and its significance in the context of this passage, will be further explored below.

${ }^{2}$ For more on whom see Chapter 3 below.

3 Val. Max. 7.I.I of Q. Metellus Macedonicus. For the close relation between fecundity (fecunditas) and pudicitia in Roman thought see also Livy 42.34.3; Sen. Dial. I2.I6.3 (cited below); Tac. Ann. I.4I.2 (see Chapter 7 below).

${ }^{4}$ For the visual quality of pudicitia cf. Pompon. I.46 where pudicitia is 'distinguished' (insignis); Tac. Ann. I.4I.2 where it is praeclara; for further references to the need for pudicitia to be visually evident see below, pp. 69-73.

5 Val. Max. 2.I.3; other references discussed below. $\quad{ }^{6}$ See Forbis 1990, Lattimore 1962.

7 It has been translated thus recently (and these examples are taken more or less at random) by Cape 2002: 207 and Rives 1999: 205. I am not suggesting, of course, that their uses of the term are ludicrous, since their contexts do not require them to put the pressure on the definition that mine does; the references merely illustrate that this is one of the current standard translations of pudicitia into English.

8 'Chastity' is the most common translation of pudicitia into English in current scholarship: e.g. Cantarella 1987: I51; Palmer's 1974 article describes pudicitia as 'female chastity' throughout.

9 A comparison might be made with the contemporary phenomenon of evangelical Christian abstinence 'The Silver Ring Thing', which is all about display; photographs of large groups of teenagers holding out their rings for the camera adorn the official website at www.silverringthing.com. 
My first chapter, then, will focus on one aspect of a sexual virtue in the Roman culture of display: the phenomenon of the ritual cultivation of pudicitia as divinity, with the associated themes and narratives that emerge from the sources that mention such cultivation. We will explore this key aspect of pudicitia's role in the public domain, its association with married women, and implications of the sources' insistence on the centrality of visual display. Whereas Thucydides loudly proclaims the virtues of remaining silent on the subject of women, ${ }^{10}$ Roman sources declare that pudicitia must be publicised. However, they remain properly imprecise about the details of its publicity, shying away from the actualities of cult practice or detailed physical descriptions of virtuous women; our sources are coy or marginal.

\section{PUDICITIA AS GODDESS}

Pudicitia is one of many abstract moral qualities that manifest as divine beings in Roman culture. ${ }^{\text {II }}$ She appears in the lists of divinities reeled off by sceptics such as Pliny the Elder. References to such a deity or personification in extant literature are sparse, but they do span our whole period of concern, from Plautus' Amphitryo to Juvenal's sixth satire and beyond. ${ }^{\text {I2 }}$ Identification of such references is complicated by the fact that Latin does not distinguish between lower-and upper-case letters, and thus Pudicitia and pudicitia are one and the same, allowing a slippage between the active divine being, controlling the lives of mortals from without, and the virtue within. ${ }^{13}$ However, from the late first century CE, pudicitia is also represented visually as a personified figure on coins produced by men and women of the imperial family, ${ }^{\mathrm{I}}$ and possibly on other, large-scale monuments such as the Forum Transitorium. ${ }^{15}$

Pudicitia was a real and powerful presence in the life of the city, impinging on the ethical development of individuals, as an invocation to her in the work of the early imperial moralist Valerius Maximus attests. In a brief

Io Thuc. 2.45.2.

II See Introduction, pp. 25-7 above and Beard, North and Price 1998, vol. I: 62, Fears 1981, Axtell

1907, Mueller 2002 and Feeney 1998: 87-92.
${ }_{12}$ Plaut. Amph. 929 (see Chapter 4 below, p. 218), Livy 1.58.5 (see Chapter 2 below, p. 91); Cic. Verr. 3.6 (see Chapter 6 below, p. 290); Cic. Catit. 2.25 (see Chapter 6 below, p. 283); Calp. Decl. 3 (see Chapter 5 below, p. 272); Val. Max. 6.I.praef. (discussed below and Chapter 3); Mart. 6.7.I; Juv. 6.I and I4 (discussed below, p. 55); Plin. Nat. 2.I4.I.

13 I shall usually use the lower case to refer to all manifestations of pudicitia throughout, so as to maintain this flexibility, but where it is the personification that is specifically indicated I shall use the upper case.

${ }^{14}$ For representations of Pudicitia on imperial coinage see Mueller 2002: 24-6.

${ }_{15}$ Such is the argument of D'Ambra 1993. 
preface to a chapter of anecdotes illustrative of the virtue of pudicitia, he addresses the personified quality as a deity, invoking her in the formal language of prayer and suggesting that she is responsible for inspiring the catalogue of deeds that follow: ${ }^{16}$

unde te virorum pariter ac feminarum praecipuum firmamentum, pudicitia, invocem? tu enim prisca religione consecratos Vestae focos incolis, tu Capitolinae Iunonis pulvinaribus incubas, tu Palati columen augustos penates sanctissimumque Iuliae genialem torum adsidua statione celebras, tuo praesidio puerilis aetatis insignia munita sunt, tui numinis respectu sincerus iuventae flos permanet, te custode matronalis stola censetur: ades igitur et cognosce quae fieri ipsa voluisti.

From where shall I invoke you, pudicitia, the principal foundation of men and women together? For you inhabit the hearths which according to ancient religion are sacred to Vesta, you lie on the sacred couches of Capitoline Juno, on the summit of the Palatine you celebrate the majestic household gods and the most sacred Julian marriage bed, standing by at all times; the glories of childhood are defended by your protection, the flower of youth remains pure out of respect for your divine power, the matronal robe is esteemed because you are its guard. Therefore come near and know again of those events that you yourself willed to come about (Val. Max. 6.I.praef.).

Valerius starts with a formal invocation of the deity, and proceeds by listing the places and the roles associated with her; finally pudicitia is invited to step out of the parade of exemplary figures and join the author and reader as spectator at the show of exempla to follow. ${ }^{17}$ The formal hymnic anaphora emphasises her direct involvement in Roman life; using the repetition of the second person singular pronoun $(t u \ldots t u \ldots t u \ldots t u o \ldots t u i \ldots t e)$ at the head of each phrase, Valerius first describes her numinous presence in three key political and religious locations in the heart of Rome - the temple of Vesta, ${ }^{18}$ the temple of Juno on the Capitoline, ${ }^{19}$ and the seat of the Julian

${ }^{16}$ For a full discussion of this text see Chapter 3 below.

17 For the structure of a formal invocation see Norden 1956: 143-63. The proem to Lucretius' De rerum natura or Catul. 34 are further examples of the same structure in Latin literature. For exempla see further Chapters 2 and 3 below.

i8 On the hearths, temple and cult of Vesta, with its associations with castitas, fertility and the wellbeing of the city see Beard, North and Price 1998 vol. I: 5I-4; see also 189-9I for the close association of Vesta with the imperial family under Augustus. See Mueller 2002: 44-68 on the representation of Vesta in Valerius Maximus.

ig Juno was one of three deities (with Jupiter and Minerva) celebrated in the Capitolium, on the Capitoline hill overlooking the forum, at the centre of Roman religious practice. Like the temple of Vesta, supposed to have housed sacred items brought from Troy, this was an institution that traced its history from the very origins of the Roman city. The goddess Juno was associated with marriage and childbirth; see further Mueller 1998 for the significance of her association here with pudicitia. 
imperial family on the Palatine $e^{20}$ - and then specifies three sets of people with whom she is connected: children, youths and married women (pueri, iuvenes and matronae).

The key vocabulary is of protection, and the military resonance of adsidua statione ('standing by at all times') in the earlier phrase is picked up and expanded on in the second half of Valerius' description: pudicitia is a guard (custos) under whose protective care (praesidium) Roman citizens are defended (munita). Pudicitia is the guard who defends the insignia of childhood, respect for her godhead allows the flower of youth to remain pure (sincerus), and it is because she is its guardian that the matronal rank is esteemed. Each group that she protects is described in a manner suggestive of the related concepts of social status, attractiveness, and vulnerability. ${ }^{21}$ The insignia of young male children (the bulla - an amulet worn around the neck) and the stolae (long robes) of married women are the items which they wear to mark them out visually from other members of society and which indicate the freeborn status which makes assaulting them an offence; ${ }^{22}$ in Roman society it should instantly be clear which people are untouchable, and the visuality of status and sexual vulnerability is clear.

The stories that follow are of individuals manifesting and enacting the quality of pudicitia in a series of startling and unusually violent deeds. In Chapter 3 I shall analyse in detail Valerius' text, and its representation and problematisation of the concept of pudicitia. Here it shall suffice to notice that there is a direct relationship between this goddess and the moral quality that will be illustrated in the rest of Valerius' chapter. He describes the goddess as having willed the deeds of pudicitia to take place and as now once again overseeing their enactment; she is fully aware of and involved in both the moral activities of mortals and the handing down of moral principles. The passage suggests her direct intervention through inspiration into the ethical lives of mortals, and as a power manifested through Roman people. ${ }^{23}$ Furthermore, the opening line of the passage advertises the fundamental significance of pudicitia to both men and women - an important claim that will be further explored in Chapter 3 below.

20 There is much at stake in pudicitia's association with the imperial household. The work, addressed to the emperor as moral leader, is written during the rule of Tiberius when the principate is establishing power partly through strategies of engaging with the moral life of its subjects; see Chapter 7 below and Langlands 2000 , Part II.

2I All the groups mentioned here also require legal protection from an adult male; see above Introduction, pp. 20-I.

22 On the idea that Augustus had recently re-established the wearing of the stola by women as part of a new visual language of politics and morality see Sebesta 1998.

23 For more on gods (and particularly Pudicitia) as interested in mortal ethics see Mueller 2002, esp. Chapter I. 
Valerius Maximus does not mention a specific shrine or cult devoted to Pudicitia, but other ancient sources, Livy and Festus (examined below), speak of two separate shrines (sacella) in the city of Rome housing her statue (an original shrine in the Forum Boarium, near the temple of Hercules, and a more recent, plebeian shrine in the Vicus Longus). ${ }^{24}$ These sources state that participation in the rituals was restricted to married women of proven sexual virtue who had only been married once. In such cult practice Romans created for certain virtues a visible and tangible form and then, by publicly displaying representations of them and coming together to cultivate them as deities, showed how important such qualities were for the community and for the state itself. An account of such activity influenced by anthropological methodology recognises the cultivation of civic shrines as an important form of engagement with moral issues for the ancient Romans. Through participation in public ritual, citizens of Rome participated in their community, and before the eyes of their community, and acted out a public endorsement of certain key values that were felt to hold the community together. Through their communal performance of ritual, as well as through their role as spectators of ritual, members of Roman society were able to internalise the structures of moral thought that would make them functioning citizens - or at least so our elite-authored sources would have us believe.

Cult practice enshrines aspects of Roman ideology in a non-textual medium, without philosophical discussion. To study cults is to approach a different register of moral thought from that which we find in many of our elite sources. Ritual is a mode of communication which can reach the illiterate and the uneducated through symbol and gesture, and whose ethical significance resonates throughout all ranks of society. The cult and ritual practice of other cultures has long been subject to anthropological analysis, which is felt to offer an outsider an alternative path of access to the mindset of an alien community to that offered by text and spoken word. ${ }^{25}$

The first mode of discourse about pudicitia that I should like to examine, then, is that of ritual and cult practice - but, unfortunately, this is a tantalising impossibility. In an ideal world we would be in a position to analyse the rituals involved in tending the cult of Pudicitia first-hand, just as Clifford

24 See Palmer 1974. The Forum Boarium was a public space in Rome with a long history to which many stories were attached; it was the site of the Ara Maxima associated with Hercules (Varro Ling. 5.I46, Fest. p. 349L, Prop. 4.9.19-20, Ov. Fast. 6.477-8). The Vicus Longus was a residential street between the Quirinal and Viminal hills, with strong associations with plebeian history. See Steinby 1999: 167-9 and Richardson 1992: 32I-2.

25 Feeney 1998: 117. 
Geertz, in an exemplary piece of anthropological analysis, observed, broke down and made sense of the rituals of the Balinese cock fight in terms of a wider social system of meaning. ${ }^{26}$ As Classicists, however, we are used to the cold trail and the inability to get in among our subjects. At the very least, however, we might hope to be able to analyse aspects of the ritual as chronicled by the ancient authors themselves, as Ariadne Staples has done for a number of Roman cults in which women participated. She has studied various aspects of cult practice (such as the status of participants, the nature of the rituals that are performed, and the mythical tales associated with a cult) in order to show how they work to dramatise and act out the sticky issues in Roman ideology, to set up and reaffirm boundaries and categories of thought, help to reinforce types of behaviour and to affirm the community of all these ideas. ${ }^{27}$

In the case of the cult of pudicitia, no such luck. The ancient sources do have some ancient description of other cult practices associated with the quality of pudicitia (which I shall come on to later in this chapter), ${ }^{28}$ but there is no actual description of the cult or rituals of the deity Pudicitia herself. If there ever were accounts they are long gone, and we have no opportunity, unlike the modern anthropologist, to witness and interpret the activities of the participants in the cult ourselves. We must rely on piecing together a sense of what the cult might have involved and what it might have meant to the Romans from a miscellaneous yet severely restricted range of sources, hoping to make the Romans articulate anew answers to our own questions.

In addition, when we do have relevant source material, there are also issues about how we are to interpret ancient texts that engage with the topics of ritual and cult. Feeney points out that even our apparently most revealing sources about Roman cult are highly problematic. There is a startling discrepancy, for instance, in the case of the cult of the Bona Dea, for which we happen to have ample source material, between the evidence of the ancient literature and that of the archaeological sources. ${ }^{29}$ As Feeney emphasises, the literary texts that write about cult (of which Ovid's Fasti is a prominent and paradigmatically puzzling example, discussed later in this chapter) represent in themselves interpretation or exegesis of their subject rather than description, and must be taken as participants in their own form of cultural practice, rather than standing back to observe it impartially. ${ }^{30}$

\footnotetext{
26 'Deep play: notes on a Balinese cockfight' in Geertz I973: 3-30.

27 Staples 1997. These female cults are often shown to pertain to the sexuality of both men and women.

${ }^{28}$ See also Palmer 1974 and Staples 1997. 29 Feeney 1998: 17-18.

30 Cf. Bourdieu 1977 on the idea of the theory of practice.
} 
What ancient texts say about ritual is very valuable, but we must not succumb to the temptation to take them as expert or reliable informants about the reality of ritual. ${ }^{31}$

While providing an introduction to some aspects of the significance of the ancient term pudicitia in Roman society, then, this preliminary analysis of ancient material relating to the cult will also provide an opportunity to reflect on the nature of our sources. I shall first examine Livy's account of the foundation of the plebeian version of the cult of the goddess, within his narrative of the third-century social tensions between the patrician and plebeian orders, in the context of elite self-definition and competition for honour within and between different social groupings. Other than Livy's account of a particular moment in the cult's history, we have only two brief references to the existence of shrines to Pudicitia by the erotically subversive and satirical poets Propertius (late first century BCE) and Juvenal (early second century CE). This very lack of evidence suggests that the cult of such a virtue was hard to publicise, because of its sensitive nature; the dangers of speaking out about and showing off pudicitia will be further explored throughout this chapter.

\section{THE CULT OF PUDICITIA}

Livy's history, inevitably rooted in its own extraordinary era of transition between republic and imperial rule, and in its own concerns, relates a founding myth that is clearly not so much description of a living cult as fraught reflection upon a cult that no longer flourished. Written in the late first century BCE, it describes the events of one particular year (almost three centuries earlier) that was marked out by an argument that flared up during the public performance of cultic rituals and led to establishment of a second cult of pudicitia for plebeian women:

eo anno prodigia multa fuerunt, quorum averruncandorum causa supplicationes in biduum senatus decrevit; publice vinum ac tus praebitum; supplicatum iere frequentes viri feminaeque. insignem supplicationem fecit certamen in sacello Pudicitiae Patriciae, quae in foro bouario est ad aedem rotundam Herculis, inter matronas ortum. Verginiam Auli filiam, patriciam plebeio nuptam, L. Volumnio consuli, matronae quod e patribus enupsisset sacris arcuerant. brevis altercatio inde ex iracundia muliebri in contentionem animorum exarsit, cum se Verginia et patriciam et pudicam in Patriciae Pudicitiae templum ingressam, ut uni nuptam ad quem virgo deducta sit, nec se viri honorumve eius ac rerum gestarum paenitere

31 Cf. Fantham's caveats about Ovid's Fasti as a source about women's religion (Fantham 2002), Beard, North and Price I998 vol. I: 6-7. 
ex vero gloriaretur. facto deinde egregio magnifica verba adauxit. in vico Longo ubi habitabat, ex parte aedium quod satis esset loci modico sacello exclusit aramque ibi posuit et convocatis plebeiis matronis conquesta iniuriam patriciarum, 'hanc ego aram' inquit, 'Pudicitiae Plebeiae dedico; vosque hortor ut, quod certamen virtutis viros in hac civitate tenet, hoc pudicitiae inter matronas sit detisque operam ut haec ara quam illa, si quid potest, sanctius et a castioribus coli dicatur.' eodem ferme ritu et haec ara quo illa antiquior culta est, ut nulla nisi spectatae pudicitiae matrona et quae uni viro nupta fuisset ius sacrificandi haberet; volgata dein religio a pollutis, nec matronis solum sed omnis ordinis feminis, postremo in oblivionem venit.

In that year $[296 \mathrm{BCE}]$ there were many prodigies, and the senate decreed a twoday period of public prayer to avert the troubles; wine and incense were distributed publicly; men and women went to celebrate the rituals en masse. A rivalry that arose among the matronae in the sanctuary of Patrician Pudicitia, which is in the Forum Boarium near the round temple of Hercules, made this celebration particularly noteworthy. Verginia, the daughter of Aulus, was a patrician woman who was married to a plebeian, the consul L. Volumnius; the matronae excluded her from the sacred rites on the grounds that she had married out of the patrician order. A short dispute then blazed from feminine argumentativeness into a fullblown controversy, when Verginia boasted that she, both a patrician and a pudica, had entered the temple of Patrician Pudicitia as one married to a man to whom she had been given as a virgin, and that she had absolutely no regrets about her husband either in terms of his official positions or in terms of his achievements. She then added to these magnificent words an illustrious deed. In the Vicus Longus where she lived, she shut off part of a building where there was enough space for a smallish sanctuary, and put up an altar here, and having made strong complaints about the injustice perpetrated by the patrician women to an assembly of plebeian matronae, she said: 'I dedicate this altar to Plebeian Pudicitia, and I urge you that the rivalry for courage that binds the men of this society should exist among women for pudicitia, and that you may strive that, if possible, this altar shall be said to be more sacred than the first, and to be cultivated by women who are more chaste.' And this altar too was worshipped with practically the same rites as the more ancient one: no woman had the right to sacrifice unless she was a matron of manifest pudicitia, and she had only been married to one man. Later the ceremonies were devalued [volgata] by women who were contaminated [pollutis], and not only by matronae but by all ranks of women, and finally they were completely forgotten (Livy IO.23.I-IO).

The whole lifespan of the cult is described within this passage, from uncertain origins to the sealed tomb. The final sentence claims that the cult has by Livy's own time fallen into oblivion after suffering unspecified desecration at some point in its 300-year history. This refrain of the cult's decline will echo in several other sources, and it forms part of a broader narration of moral decline and contemporary inadequacy set out in Livy's 
work. ${ }^{32}$ However, Livy speaks of the original shrine itself, the one in the Forum Boarium, in the present tense, as if this sacred space, at least, still survives in his own day, after the demise of the Republic, although his contemporary readers need to be advised of its location; in this time of upheaval such themes of loss and survival are often in evidence.

Of the practice of the two cults, the actual rituals involved, other than the fact that they are very similar to one another almost nothing is revealed except about the status of those people who are permitted to cultivate the shrine. In this account the participants are all married women, matronae, whether patrician or plebeian, and the ritual requirements as reported by Livy place yet further restrictions on the membership of the group: they must be of manifest pudicitia and they must have been married only once. This group is also marked out in ritual contexts elsewhere, although the assorted sources do not provide a clear picture of precisely which cults they tended. ${ }^{33}$ Several key themes emerge from analysis of the passage and will be discussed in the following pages: the relationship between pudicitia and the state of being univira (a one-man woman), and the problem of how her commitment to one man can ever be proved of a woman during her lifetime; the related issues of how to display pudicitia; the relationship between religion and the institutions of government, and the intersection of the history of the development of state religion with the personal moral duties of Roman individuals; the significance of the conflict between different social classes, the historical moment that is captured in the narrative about the plebeian cult's foundation, and the role of pudicitia in helping to define problematic status boundaries in the history of Rome; civic competition for honour, and the direct ethical engagement of women with such competition.

In subsequent chapters we shall see that married women are not the only kinds of people who may possess the quality of pudicitia or for whom it is vitally important, ${ }^{34}$ but the nature of the cult indicates that they have some special relationship with the quality. This special relationship flags the importance of the marital relations between husband and wife in Roman culture. We shall see that Roman sources often represent the idea of a woman having sex with someone who is not her husband as deeply troubling. ${ }^{35}$ 'He who spoils' (the Latin verb is adulterare, 'adulterate') someone else's

32 For a discussion of morality in Livy see Walsh 1961, esp. 46-109, and Chaplin 2000 passim.

33 See discussion of related cults below and Staples 1997.

34 See the end of Chapter 2 below and especially Chapter 6 on the display of pudicitia by men in the public sphere.

35 See also Williams 1999, Edwards 1993, and much of this volume. 
wife - as adulterer, or, in Latin, adulter - is always the villain of the piece. Such a circumstance often evokes a degree of horror and disgust that today might be associated with sexual intercourse with children. ${ }^{36}$ One anthropological explanation for this attitude to female sexuality is that in a patriarchal society such as that of ancient Rome, secure paternity is important and a husband wants a wife who can only have been impregnated by him. ${ }^{37}$ In Livy's story about the cult's foundation Verginia boasts that she was a virgo (virgin) when she married her husband, that she had had no previous relationship with men. The story places high value on this uncomplicated relationship between husband and wife. ${ }^{38}$ The structure of the cult places responsibility for the symbolic cultivation of pudicitia (and perhaps therefore the relations between husband and wife) in the hands of the married women, rather than those of their husbands. This highlights the women's control of their own sexuality in addition to any external controls that might be imposed on them by the community and by their husband. The regulation of a wife's sexual behaviour is in part driven by her own internalised attitudes. Participation in this cult brings home to the women how important pudicitia is and also conveys their virtue to others.

The strictures of the prohibition on those tending the shrine merit closer attention and have been extensively discussed by other scholars, most recently Nicole Böels-Janssen. ${ }^{39}$ In Livy's account women do not have the right to participate in the cult (ius sacrificandi) unless their pudicitia is manifest (spectata) - has been witnessed and attested - and they have been married to one man only. A range of questions present themselves, some of which - what did it mean to witness pudicitia? how could it be made manifest? in what sort of deed was it evident? - are central to Roman sexual ethics and will be recurrent themes of this book. Another set of issues focuses on the required status of univira - being a 'one-man woman' - which is usually taken to mean a woman who has married only once. ${ }^{40}$ That this quality was valued among Roman women, including those beyond elite status and throughout the geographical empire, can be seen from the evidence

${ }^{36}$ Cf. the discussion of modern 'paedophilia' in the Introduction above, pp. II-I2.

37 However, an interesting feature of Roman kinship structures is the widespread role of adoption, which means that blood line was not always crucial in Roman inheritance; divorce and remarriage also seem to have been common, and in many ways Rome does not conform to conventional ideas about patriarchy, despite the dominance of the paterfamilias and the strict control of female sexuality. See Gardner 1998: II4-208, Corbier 1991, Edwards 1993: 49-50, Rawson 1986: I2, Dixon 1992: II2-I3.

3. See Treggiari I99I for marital ideals in ancient Rome, esp. 229-26I; cf. Catul. 6I, Val. Max. 2.I.3-6, discussed in Chapter 3 below, pp. 126-32.

39 Böels-Janssen 1996.

to See Treggiari 1991: 233-6, Böels-Janssen 1996, Williams 1958, Gardner 1986. 
of inscriptions. ${ }^{4 \mathrm{I}}$ Why is this a requisite of participants in cult worship of pudicitia as a goddess, and what can it tell us about pudicitia? The prohibition appears to exclude from the cult all women who have remarried (or been involved with more than one man) whatever their circumstances, even if they have been widowed and their first husband is not alive.

Böels-Janssen's explanation for this prohibition from the cult of women who are not univirae, outlined in a thought-provoking article that attempts to reconstruct from the available literary sources the original lex templi of the cult of Pudicitia, ${ }^{42}$ is that it derives from traditional Roman notions of ritual purity and the risk of contagion through contact with the impure. Central to her argument is the thesis that, at the time when the shrine was founded, the quality of pudicitia did not pertain at all to the personal morality of a woman, but only to her physical state. A woman who had had sex with more than one man for whatever reason was soiled, and she was prohibited from touching the cult statue because of the risk of contagion from ritual impurity. The argument, in other words, is that the prohibition stems from religious rather than ethical considerations: the temple law does not distinguish a remarried widow from an adulteress or a woman who has been raped; all have lost their univira status by having sex with more than one man. Sexual intercourse with a particular man wreaks physical change on a woman; he lays his imprint upon her and afterwards, Böels-Janssen argues, she can never again come to another man as pudica.

The denial of the ethical dimension of pudicitia rests on a perceived distinction between the concepts of pudor and pudicitia, according to which pudor is a moral quality whereas pudicitia describes a physical state. BöelsJanssen argues that pudor is a moral term denoting the sense of shame which prevents bad behaviour, whereas pudicitia belongs to the physical realm and means purity, the absence of sexual defilement. This, she argues, must be the older, original sense of pudicitia, which pertained when the rules of the temple were first laid down. By Livy's time, she suggests, there have been shifts in the meaning of pudicitia, and his account adds a new dimension to the cult with the phrase spectata pudicitia, which introduces moral criteria alongside the previous criterion of ritual purity.

41 See Lattimore 1962, Forbis 1990, Treggiari 1991: 233-5, Forbis 1996.

42 That is, the inscription which would have been displayed somewhere on the building setting out the formal rules of participation in the cult. Through comparison of Livy's phrase 'that no woman had the right to sacrifice unless she was a matron of manifest pudicitia, and she had only been married to one man' (ut nulla nisi spectatae pudicitiae matrona et quae uni viro nupta fuisset ius sacrificandi haberet) with that of Festus ('it was a crime to touch the statue', signum nefas est attingi) Böels-Janssen concludes that the prohibition read something like this: ne qua Pudicitiae (aut Fortunae Muliebris) signum tangito nisi quae semel nupta est: 'Let no woman touch the statue of Pudicitia (or of Fortuna Muliebris) unless she has been married only once.' 
It is salutary to be reminded of the possibility, indeed the inevitability, that the meanings of a term will change over the passing of time. The restriction of the cult to univirae may have been a custom which looked puzzling or out-of-date by the time Livy came to write about it, and it may well be mistaken to turn to it for elucidation of the concept of pudicitia as it was conceived of in the late Republic. ${ }^{43} \mathrm{I}$ am not wholly satisfied by Böels-Janssen's chronological solution, but she is absolutely right to point out the discrepancies in the way that the term pudicitia is used: sometimes it appears to mean, just as she claims, the physical state of being sexually untouched, at other times it seems to describe a moral quality. It is the contention of this book that it is a central concern of Roman sexual ethics to examine precisely this ambiguity of meaning, and the problem of the dislocation between the body itself and the moral purpose of an individual. Much of the source material that I refer to throughout this book engages the reader in just such questions as where in an individual pudicitia is to be found and how its presence or absence might be recognised, and in issues revolving around the relation of the moral agent to his or her body.

\section{THE FOUNDATION MYTH}

Livy's account portrays the worship of pudicitia as fully integrated into the official practices of Roman civic life. ${ }^{44}$ Here it constitutes part of a broader, formal, civic response to national troubles in the year $296 \mathrm{BCE}$ during a period when Rome was engaged in a series of wars in neighbouring regions of Italy. This response, in the form of two days of public celebration of rituals across the city, is instigated from on high by the senate, financed, presumably, from public coffers, and fulfilled by large numbers of men and women. This is a community event and the streets of Rome are thronged with citizens pulling their weight in order to appease the gods and deflect the threatened misfortune. ${ }^{45}$ The communicatory aspect of cult worship is clear - the cultivation of shrines is part of a mutual relationship between the divine and mortal: signs of disapproval are sent from the sky, conciliatory responses are made in Rome, circumstances change for the better. ${ }^{46}$

43 Indeed it has been suggested that Livy's account is designed to make sense of the epithet Plebeia, and that in fact he confuses the cult of Pudicitia with that of Fortuna Virgo (Wissowa 1971: 257).

44 Although strictly it was part of private rather than state religion; see Palmer 1974.

45 For the theme of religion in Livy see e.g. Levene 1993: 244: 'Livy centres his treatment of religion around clear moral premises ... this morality is then consistently linked with divine favour or disfavour and consequent success or failure for Rome', or 77: 'piety is rewarded, impiety punished, and Roman victory guaranteed in advance by the gods'. Cf. Walsh 196r: 46 on the invasion of the Gauls treated by Livy in Book 5 as a disaster caused by Roman failing in the virtues of fides and pietas and the consequent incurrence of divine displeasure.

46 Feeney 1998: 82, Bloch 1963. 
The array of divine beings to whom pudicitia belongs wield considerable power over the fate of Rome and of her people, and the celebration of the cult is an act of supplication to a goddess which hopes to enlist her support for Rome against hostile forces. 'Sexual Virtue', then, is a beneficent power whose patronage the state of Rome needs. She is one of many such powers, yet her role is important, affecting areas of a Roman citizen's life beyond those directly related to the sexual: politics, military, not to mention such natural phenomena as famine, droughts and floods. Although state religious practice in Rome fragmented into the acknowledgement of many divine beings, every unit was part of a large organic whole, in which every aspect of public life, state and community was implicated. Of particular interest here is the fact that Livy portrays the Romans as a community considering the quality of pudicitia to belong to this public realm.

The narrative belongs to two of the broader politico-historical narrative strands of Livy's history: first, the gradual accretion and development of Roman religious practices and second, the so-called 'Struggle of the Orders' between the plebeian and the patrician classes. The women who initially celebrate the cult are all patrician and they ban Verginia from tending the shrine alongside them on the grounds that she has forfeited her patrician status through her marriage to a plebeian man, albeit one of high rank indeed a consul. Livy binds the story of their dispute and the establishment of the new cult into a wider narrative about the conflict between the old power of the patricians and the emerging demands of the plebeians, which results in gradual expansion of plebeian franchise. ${ }^{47}$ Participation in rites is an important way of establishing and proclaiming political and social status, as this account suggests. Other related cults, such as those of Fortuna Muliebris and Venus (also celebrating the quality of pudicitia), seem to have had similar associations with this overarching narrative of political conflict and change..$^{8}$

Healthy competition is an important aspect of the tale. Livy calls the original dispute in the temple of Pudicitia a certamen (competition) and a

47 For more on this see the following chapter, where another key Livian narrative or exemplum that treats the subject of pudicitia will be discussed. This story not only has a central protagonist of the same name - Verginia - but also constitutes a turning point in Livy's narrative of relations between patrician and plebeian. The patrician Appius Claudius' attempted abduction of the plebeian virgin Verginia, dramatically thwarted by her father, precipitates the overthrow of the decemvirate and the restoration of the post of tribune of the plebs, the magistrate who represents the plebeian masses and gives them a voice among the ruling bodies.

$4^{8}$ See Palmer 1974, Staples 1997, Böels-Janssen 1996, especially on Fortuna Muliebris and cults of Venus. 
contentio animorum (contest of minds), initially between Verginia and the other patrician women. Verginia's inaugural speech to the plebeian women emphasises a rich network of competitive relations. The women of Rome must take up the challenge of the men, among whom there is supposed to have flourished a tradition of rivalry in the field of virtus (military courage and moral excellence) which is extensively documented by Livy and his contemporaries. ${ }^{49}$ While the men compete among themselves to be the most virtuous, the most courageous, to be considered endowed with the greatest virtus, the matronae whom Verginia addresses are urged to compete among themselves for pudicitia. Lastly, Verginia hopes that this competition among the plebeian matronae will result in an excellence in pudicitia that will lead the high repute of the plebeian shrine to outstrip that of the original patrician shrine: they should strive that the altar may be considered more sacred and the women themselves thought to be the chaster.

Three hundred years after the events which he purports to relay, Livy is portraying the public cultivation of the goddess' shrine as the complement of the personal cultivation of the moral quality by the women who tend it. Just as the shrine must be sacred (sanctus) and seen to be sacred, so the women must themselves be pure (castae $)^{50}$ and seen to be pure. Livy's firstcentury BCE text suggests an intimate connection between ritual practice and moral life, between the public face of the cult and the personal ethics of its celebrants outside the ritual time and space. It also suggests that the cults were concerned to engage with the women as ethical subjects, in parallel with men. Verginia's words imply that pudicitia is one virtue in particular with which women were engaged, and that the field of sexual ethics is a particular space within Roman ethics marked out for women. More puzzlingly perhaps for a reader who comes with a prejudice that pudicitia equals 'chastity', the speech suggests that pudicitia is a quality of which there are degrees and in which it is possible to compete.

How women behave within their marital relations, how they are seen to conduct themselves is not, in the terms of this passage, a personal moral issue as we might understand it today: a matter for the conscience of the individual, with repercussions for the immediate family and friends only. Rather it is intimately bound up with the civic and religious duty of the individual, and with the wellbeing of the community as a whole.

49 For instance, the narrative immediately preceding this in Livy's work relates the competition between the generals Appius and Volumnius that spurs on the Roman army to compete against itself for victory and to rout the enemy easily (I0.19.18-19). Men who saved another's life in battle were awarded a corona civica (see Oakley 1998).

50 For the significance of the terms castus and sanctus see the Introduction above, 
The cult enables the public celebration of the quality of pudicitia, and in itself provides a medium through which women can parade their individual endowment with pudicitia before the community. Livy's foundation myth holds up Verginia as illustrious exemplar because she speaks out and acts on behalf of the plebeian order despite being herself by birth a patrician. Her deed is also lauded because she makes a public show about the importance of pudicitia to society, and the importance of being associated with the quality for individual women. The story underlines the fact that participation in public cults is (or rather was in an idealised past) an essential part of belonging and contributing to society in general. Verginia is furious at being excluded from the cult by the other patrician women because it is a social snub, but also because it deprives her of a formal space in which to act out her pudicitia for all to see. Exclusion from the cult leaves a pudica woman without a means of celebrating, and thereby making sense of, this state. By her subsequent actions she provides such facilities for plebeian women throughout the city too. With a cult of their own they may participate fully in this important aspect of cultural life, in the mediation of the relationship between human and divine, and the maintenance of the health of the Roman state. Pudicitia helps both to mark distinctions between women of different status, and to integrate the plebeians into the community.

The story speaks to the ethical subjectivity of women. The women maintain their own moral standards and regulate their own behaviour (or at least send messages to others about such standards and behaviour) with reference to public celebration and to the gods. Livy also makes clear that this pleasing system is no longer operating; the cult is no longer tended. The cult lost its exclusivity and was infiltrated by all kinds of women - women who were not matronae - and is now gone. Yet this very retelling of its foundation serves to an extent to resuscitate some of the functions of the cult; this story emphasises the importance of pudicitia, among other things, and portrays women as having control over their own morality.

That there was felt to be a close association between religious cult and personal ethics is clear, the nature of the association less so. The ethical significance of the shrine is underlined by references to it by Propertius and Juvenal. The poems alluding to the shrine both draw clear links between the celebration of the cult and treatment of the shrine on the one hand, and the maintenance of standards of social and sexual behaviour of individuals generally on the other. 
Propertius mentions the shrine in elegy 2.6, in which he is lamenting the moral state of the girls of his day and in particular that of Cynthia, about whom much of his love poetry has so far obsessed. The poem begins with Cynthia described as super-courtesan welcoming all comers, and ends with her described as faithful wife. ${ }^{5 \mathrm{I}}$ Linking these opening and closing images are the paranoid jealousy of the poet and his notion that girls are sexually corrupted by the pictures of sexual intercourse that surround them in the domestic setting, which we might justifiably identify as the kind of paintings that have been preserved on walls of buildings in Pompeii. ${ }^{52}$ These two elements of the poem evoke the tensions between two recurrent features that fire the passion of elegiac poetry: the context of sexual licence and the possessiveness of the lover. ${ }^{53}$

Propertius begins by evoking Cynthia's promiscuity; her house is thronged with men so that in her welcome she outstrips even the renowned Greek courtesans Lais and Thais and Phryne (lines I-6). This image is undermined as we realise that we are looking through the distorting lens of the gaze of the jealous lover; even the slightest, most innocent thing can send Propertius into agonies of jealousy, as his imagination manufactures grounds for suspicion (7-r4). This kind of tormented lust and jealousy, the poem continues, has been the cause of trouble before, and we move from Helen, whose beauty and fickleness precipitated the Trojan war, through the Centaurs' brutal disruption of the Lapith wedding, to Rome itself: right from the start the very founder of Rome, Romulus, sanctioned unprincipled lust when he organised the abduction of the Sabine women to make wives for Roman men. Since the beginning of Roman time, love does what it likes ( $15-22)$. Then the poem asks:

templa pudicitiae quid opus statuisse puellis

si cuivis nuptae quidlibet esse licet?

What is the point of having established temples to pudicitia for girls

If a bride is allowed to do whatever she likes? (Prop. 2.6.25-6).

Behind Propertius' question lies the assumption that the point of the establishment of the temple is to place constraints upon nuptae (brides or married

51 Critics have long argued about whether puellae are respectable married women or courtesans; this ambiguity is part of the fun of the genre of Roman love elegy, which plays with ideas about the status of women, as we shall see in Chapter 4 . See Lyne 1980 on the provocative use of marriage terminology by Propertius, with reference to this couplet; Wyke 1989 on scriptae puellae.

52 On such paintings and issues involved in interpretation see Clarke I998; on their possible relationship with Roman love poetry see Myerowitz 1992 and Fredrick 1995.

53 See further Chapter 4 below, pp. I96-7. 
women). Cultivation of the shrine is related to preventing women from doing as they please, and curtailing the sexual licence of Rome established by Romulus' actions. ${ }^{54}$ However, that connection seems to have weakened: the shrine is not managing to play that role. Moreover, the girls have been exposed to a competing medium, the erotic pictures that appear in domestic interiors. 55

The next pertinent lines seem to elaborate on this idea and re-establish a connection between the (abandoned) cult and abandoned ethics:

sed non immerito! velavit aranea fanum et mala desertos occupat herba deos.

But it is not undeserved! cobweb covers the shrine, and weeds occupy the deserted gods (Prop. 2.6.35-6).

Whether the reference is to gods and religion in general, or more specifically to pudicitia itself, is uncertain, as is the position of the lines in the poem, and the appropriate punctuation of the first line of the couplet. ${ }^{56}$ However, there is a clear link between the worship of a divinity through cult and the behaviour, mores, of Roman women. ${ }^{77}$ It is not so much that one causes the other, but that the two are mutually reinforcing; part of the behaviour inspired by pudicitia is the tending of the cult of the personification; this commitment to the cult in turn strengthens pudicitia as a force in society and as a divine force guarding over society, further inspiring individuals within society.

Propertius locates the shrine in the distant past, but he also locates sexual licence right at the beginning of Rome's history and the corruption of women far in the past as well. There is no logical chronological sense to be found in this poetic evocation of Roman sexual mores; the opposing forces are tangled up together in the past. Propertius is deliberately problematising a simple chronological account of moral decline, and his own account makes it harder to differentiate between wrongful and rightful sexual behaviour. Lust is embedded in Rome's history and identity, and Romulus, the role model and heroic founder of the city, encourages men not to resist their libidinous urges. The shrine of pudicitia is associated with female sexual ethics, but it is only one of a range of competing media, and fails to regulate sexual behaviour authoritatively. Propertius tells a different story from that

54 The married women's behaviour is a verbal echo of the behaviour of the erotic force himself, Amor, a couple of lines earlier, who, as a result of Romulus' abduction of the Sabine women, may now dare whatever he likes in Rome: per te nunc Romae quidlibet audet Amor, 'because of you [i.e. Romulus], Love now dares whatever he likes in Rome' (2.6.2I-2).

55 See note 52 above. $\quad{ }_{56}$ On the textual issues see Camps 1967 ad loc.

57 On the link in Roman thought between moral decay and the decay of the fabric of the city see Edwards 1996. 
of Livy; there have always existed lust and sexual licence in Rome, and it is possible to think that the shrine has never, at any point in its history, been entirely successful in its moralising intentions: resistance to its prescriptions has always been part of its history too.

Meanwhile, Juvenal's sixth satire embellishes the long-running ancient literary trope about divinity and virtue leaving the mortal world to which Propertius alludes. ${ }^{5}$ This lengthy diatribe opens with his claim that pudicitia herself has long ago abandoned the mortal realm, and that her departure has left moral chaos in its wake, and depicts the sordid consequences of the goddess pudicitia's abandoning the mortal world: sexual immorality to a grotesque degree among married women. The poem is addressed by its satiric narrator to Postumus, apparently to warn him against marriage, and seems to be an extensive poetic version of a rhetorical set piece on whether or not a man should marry. The running joke of the poem, as Susanna Braund has argued, is the invocation of traditional morals to support a case that appears to be in fundamental opposition to those morals - i.e. the case against marriage. ${ }^{59}$ Halfway through the poem, reference is made to the shrine of pudicitia, and Juvenal's satirical pen depicts a shrine that has not merely been abandoned, but is even the object of crude and unpleasant abuse by the women of Rome:

i nunc et dubita qua sorbeat aera sanna

Maura, Pudicitiae veterem cum praeterit aram,

Tullia quid dicat, notae collactea Maurae.

noctibus hic ponunt lecticas, micturiunt hic

effigiemque deae longis siphonibus implent

inque vices equitant ac Luna teste moventur,

inde domos abeunt: tu calcas luce reversa

coniugis urinam magnos visurus amicos.

Now go and ask yourself why Maura snorts the air derisively

When she passes by the ancient altar of Pudicitia,

What Tullia says, the foster sister of notorious Maura.

At night here they set down their litters and here they urinate

And cover the statue of the goddess with their long squirts,

And they take turns to ride each other and move with the moon as their witness

And then they go home: at dawn you tread in your

Wife's urine on your way to see your patrons (Juv. 6.306-13).

${ }_{58}$ Greek precedents for this topos are Hes. Op. 197-201 (on aidos) and Aratus Phaenomena (dike); see Braund 1992 for further references.

59 This is the interpretation of Braund 1992. 
Women urinate against the very effigy of the goddess and (although the text is unclear) take part in transgressive sexual practices, ${ }^{60}$ demonstrating their contempt for the deity and all that she stands for. ${ }^{61}$ These are married women - the parting shot of this vignette is to suggest that the addressee may end up paddling through his own wife's urine as he sets off for his patron's house on the following morning.

In Juvenal's depiction, Pudicitia has left the mortal realm in disgust at its immorality, but her going also has a further deleterious effect upon the mortals that she leaves behind; there is mutual reinforcement between cult and ethical behaviour. Likewise, in order to indicate their extreme immorality, the women direct their disrespect for pudicitia against the goddess' shrine and statue; their behaviour represents wilful perversity and perversion that wants to get itself noticed, rather than ignorance and neglect of traditional morality. Such barefaced grotesquery is typical of the way that sources of this imperial era (late first and early second centuries $\mathrm{CE}$ ) depict Roman engagement with the quality of pudicitia and traditional Roman morality generally. ${ }^{62}$ Juvenal's satire trumpets its heavy, moralising framework from the start, but spends its time showcasing an enthralling series of tableaux in which pudicitia is deliberately discarded and vandalised; the very moralising calls attention to the fact that the poem is itself pissing on pudicitia.

The cult of pudicitia was certainly for both Propertius and Juvenal a useful way of talking about sexual virtue among mortals. Indeed, in both passages the treatment of the cult serves as a reification of the morals of married women. Both sketch a contrast between a morally upright past and a morally corrupt present. Both are subversive and humorous genres (of which more in Chapter 4). In both cases, the ethics in question are those of women; it is their behaviour that the deity should be guiding, they whose morals are corrupted by looking at the paintings on erotic themes. Women are depicted as moral agents who should learn correct behaviour but who instead fail or deliberately disregard moral guidance, or are corrupted and led into sexual immorality. ${ }^{63}$

60 Cantarella 1987: 157 describes them as practising 'homosexual love', although it is not clear whether it is each other that they are riding or the statue of the goddess herself; the latter would be particularly shocking. Cf. Adams 1982: 165-6 who says that they take turns to ride one another.

${ }_{61}$ 'The women's attitude to Pudicitia indicates graphically their views on marriage and fidelity', Braund 1992: 75 .

${ }^{62}$ See further Chapters 4 and 7 below.

${ }^{6} 3$ For more on the nature of these texts and how they might contribute to Roman ethical discourses see Chapter 4 below. 
All the sources discussed so far describe the cult in terms of its being over, and take this as a sign of moral decline, participating (in their own ways) in a widespread Roman discourse of the degenerate present which permeates texts from the earliest times. ${ }^{64}$ Where pudicitia is concerned, however, this claim is also telling us something about the precariousness of the quality of pudicitia, which is always at risk, whether from pollution, oblivion, neglect or abuse. As far as the consequences of the cult's failure to survive go, Livy does not elaborate, Propertius focalises the faithlessness of women through the eyes of a jealous lover, and Juvenal through the eyes of an angry satirist.

Let us now return to the theme of public display of virtue and women's honour. In Livy's myth of the founding of the cult of plebeian pudicitia, national crisis leads to competition between women for honour in pudicitia, and thence to cultic innovation. This pattern is repeated in a variety of ancient sources with reference to other cults and religious innovations; in fact key moments of emergency in Roman history are often marked by incidents involving the intersection of female sexuality and state religious practice. Livy tells us (8.I8.I-II) that in 33I BCE there was a scandal involving the poisoning of several leading men of the community by their wives, which may, according to one scholar, have been the stimulus for the founding of the cult of pudicitia for patrician women; ${ }^{65}$ the establishment of a temple to Venus Obsequens in 295 BCE (the year after the dedication of our shrine to Pudicitia Plebeia) is described as a response to an adultery scandal of that year, with Fabius Gyges financing the building from the fines of the immoral women; the dedication of a statue to Venus Verticordia in 220 $\mathrm{BCE}$ and the introduction into Rome of the goddess Cybele in 205-4 BCE are both the results of demands associated with the regulation of female sexuality made by the Sibylline books in response to national crises. The ancient sources, by retelling versions of this 'crisis/female sexuality/religious innovation' story, are re-enacting such responses in order to underline the importance of maintaining control over female sexuality. This next section will look more closely at two such versions - those of Venus Verticordia and of Cybele - both of which pertain to sexual ethics and which are interpreted by the ancient sources through the same interlocking themes of women's pudicitia, national crisis and competition that we have identified in Livy's account of the founding of the cult of pudicitia.

64 See Edwards 1996 for an analysis of this discourse.

65 See Palmer 1974: 122 for this suggestion and the comment that the women's behaviour is represented as analogous to an uprising of the plebs, locating this tale too in the context of the Struggle of the Orders. 
Venus Verticordia was a particular manifestation or aspect of the Olympian goddess Venus, whose role was to turn the hearts of women away from sexual vice - hence her epithet Verticordia or 'Heart-Turner'. ${ }^{66}$ The consecration to her of a statue (dated to $220 \mathrm{BCE}$ ) was said to have been in response to the prescriptions of the Sibylline books. ${ }^{67}$ Once again the context is state-organised religious practice designed to inculcate sexual virtue among Roman females (not just matronae this time, but virgin girls too), which in turn will contribute to the wellbeing and protection of the Roman state. The consecration of the statue to the divinity was preceded by another competition amongst Roman matronae for the title of the most sexually pure. The accounts of the introduction into Roman civic life of Cybele (also known as the Great Mother, the Mother of the Gods), in 205-4 BCE, contain similar elements. ${ }^{68}$ Public acknowledgement of outstanding sexual purity in a woman (also in relation to ritual purity) is likewise a key feature of the tradition and the context is again formal cult practice organised by the senate, involving incorporation of a cult from abroad into the Roman cultic network.

Pliny the Elder pairs the two stories in his encyclopaedia:

pudicissima femina semel matronarum sententia iudicata est Sulpicia Paterculi filia, uxor Fulvi Flacci, electa ex centum praeceptis quae simulacrum Veneris ex Sibyllinis libris dedicaret, iterum religionis experimento Claudia inducta Romam deum matre.

Once upon a time Sulpicia, daughter of Paterculus and wife of Fulvius Flaccus, was judged in the opinion of the matronae the most pudica woman, chosen from a selection of a hundred as the one who would dedicate the statue of Venus according to the Sibylline books; again, in a trial of religion, Claudia [was judged most pudica] when the Mother of the Gods was brought into Rome (Nat. 7.I2O-I).

Note that his brief account focuses on the two named women who emerge from the process of selection as the best of their cohort, Sulpicia and Claudia. The word iterum (again) draws a strong comparison between

66 Although for a different account of the etymology see Ov. Fast. 4.I60, discussed below, p. 66. On this see also Fantham 2002: 36 n. 42, for the very plausible suggestion that Ovid's is a deliberately unconventional reinterpretation of the epithet.

67 A coin from $46 \mathrm{BCE}$ with a depiction of the goddess carrying scales and accompanied by Cupid can be found at Crawford 1974: 463a. Cf. Ov. Pont. 3.I.II5-18, 4.13.29 (Livia), discussed at the end of Chapter 7 below.

68 The sources which deal with introduction of the cult of Cybele or the Great Mother into Roman civic life (some of which are discussed below) have been the focus of considerable scholarly attention. See e.g. Wiseman 1979, Wiseman 1985, Stehle 1989, Fantham 1998: 153-4, Beard, North and Price r998, vol. II: $43-9$. 
the two stories and Pliny dwells on the assessment of the women's virtue by their peers or through a test - as their key aspect.

Valerius Maximus relates the story of the consecration of a statue to Venus Verticordia as part of a chapter about 'individuals who won glory for themselves' (quae cuique magnifica contingerunt), and the focus of the tale is again Sulpicia, chosen to consecrate the statue of the goddess by a select board of Roman women on the grounds of her outstanding castitas (which we can understand here as both sexual and ritual purity): ${ }^{69}$

merito virorum commemorationi Sulpicia Ser. Paterculi filia, Q. Fulvi Flacci uxor, adicitur. quae, cum senatus libris Sybillinis per decemviros inspectis censuisset ut Veneris Verticordiae simulacrum consecraretur, quo facilius virginum mulierumque mens a libidine ad pudicitiam converteretur, et ex omnibus matronibus centum, ex centum autem decem sorte de sanctissima femina iudicium facerent, cunctis castitate praelata est.

To the commemoration of men deserves to be added the tale of Sulpicia (daughter of Servius Paterculus and wife of Q. Fulvius Flaccus). When the senate had decreed, after the Sibylline books had been consulted by the decemviri, that a statue of Venus Verticordia should be consecrated so that the minds of virgins and of women should more easily be turned away from lust towards pudicitia, from all the women a hundred were chosen, and from the hundred ten picked by lot to make a judgement about who was the most morally pure (sanctissima) of women; she outshone all in chastity (castitas) (Val. Max. 8.15.12).

Once again the passage portrays the senate as instrumental in the establishment of the cult, and emphasises the importance of pudicitia to the state as a whole. Valerius interprets the role of the goddess among the Roman people as influencing the ethical core (mens) of each female citizen, whether virgin or wife, ${ }^{70}$ and as turning her away from libido (or lust) and towards pudicitia. The passage elucidates the ethical function particularly clearly: cult helps to direct the minds of citizens away from vice and towards virtue. We may note that when, as here, pudicitia is directly contrasted with libido, it must be interpreted as a moral force rather than purely as a physical state. It is explicitly the mens (mind) of the women on which the goddess must work, and this Latin term describes the moral core of an individual's being the subjective experience, moral disposition, active intellectual engagement, and moral source. The epithet Verticordia implicitly derives from the idea that the heart (cor) is the seat of subjective experience and wisdom. Once again, women are portrayed as moral agents whose moral disposition must be shaped (separately from men) by the formal structures of society.

69 See above (Introduction, p. 30) for the term castitas.

70 On the importance of pudicitia for unmarried virgins see below Chapter 2, pp. 98-102, cf. 208-9. 
This exemplum appears in a chapter devoted otherwise to the glories of men, as the introductory link suggests, so that pudicitia is implied to be the female equivalent of the civic qualities manifested in the men, and her role in the consecration of the statue the equivalent of the honours bestowed on the men of the chapter. ${ }^{71}$ The theme of the chapter is the rewards that virtue can reap - public honour and distinction - and Valerius introduces the chapter by suggesting how pleasurable to read are such stories where good deeds are justly rewarded. The didactic purpose of drawing attention to such a phenomenon is clear: the anticipation of honour and recognition by the community is a spur to the pursuit of moral excellence.

Earlier in the same chapter we also find the story of the introduction of Cybele to Rome, again with the element of competition within the community for moral excellence. However, in this version of the tale the person chosen as the best to represent the city is not Claudia (as it was in Pliny's version), but a man: Scipio Nasica.

rarum specimen honoris Scipione quoque Nasica oboritur: eius nam manibus et penatibus nondum quaestori $<\mathrm{i}>$ senatus Pythii Apollinis monitu Pessinunte accersitam deam excipi voluit, quia eodem oraculo praeceptum erat ut haec ministeria Matri deum a sanctissimo viro praestarentur. explica totos fastos, constitue omnes currus triumphales, nihil tamen morum principatu speciosius reperies.

A rare specimen of honour appears in Scipio Nasica too; for, when he was not yet quaestor, the senate wanted the goddess who had been summoned from Pessinus by a warning from the Pythian oracle to be received by his hands and by his household gods, because the same oracle had laid down that this service towards the Mother of the Gods should be discharged by the most morally pure (sanctissimus) man. Unroll all the almanacs, consider all the triumphal chariots - you will find nothing more splendid than moral pre-eminence (morum principatu) (Val. Max. 8.15.3).

The similarities between this exemplum and that of Sulpicia towards the end of the chapter are evident: they are both members of their community who are judged by others to be pre-eminent in the quality of sanctitas (de sanctissima femina, a sanctissimo viro), and chosen therefore to perform an

${ }^{11}$ In many of the preceding eleven exempla in the chapter the recognition (by senate or people) involves the bestowal of political office such as the consulship (sections I, 4, 5, 8); sometimes the protagonist earns some lasting memorial - a statue or portrait in a central location ( $\mathrm{I}$ and 2), an honorific name (5), a senatorial decree setting up the man as a model governor (6); at others the reward is merely a moment of acclaim $(7,9$, IO). In most cases the virtues celebrated are those manifested in the exclusively male roles of military commander or magistrate. However, Q. Scaevola is described as governing Asia tam sancte et tam fortiter - 'with such moral purity and such strength' - where the virtues of bravery stand proudly side by side with those of abstinence (8.15.6, and compare the people's appreciation of Cato's resistance to the lure of silver and gold at 8.15.9). These exempla also look back to Book 4 of the same work - see further Chapter 3 below for resistance to the temptations of sex and wealth. 
important religious role on behalf of that community. ${ }^{72}$ Sulpicia's virtue and the honour that it accrues are not portrayed here as exclusively or specifically associated with women. ${ }^{73}$ However, although her status and glory minutely parallel those of Scipio Nasica, only in her story is the religious phenomenon thereby inaugurated said to have explicit moral implications for others in society. ${ }^{74}$

TRADITIONAL HONOURS

We have now read a variety of versions of traditional narratives in which the assessment of matronal pudicitia is related to the founding of cults. There are also sources that refer in other contexts to the idea of public competition between women in the field of sexual virtue. For instance, Valerius Maximus writes of an ancestral custom of bestowing public honours upon women who are judged outstanding on the basis of sexual virtue. Just like the contests of virtue of Verginia or Sulpicia, these honours explicitly parallel the civic and military honours traditionally accorded to men.

quae uno contentae matrimonio fuerant corona pudicitiae honorabantur; existimabant enim praecipue matronae sincera fide incorruptum esse animum qui depositae virginitatis cubile egredi nesciret, multorum matrimoniorum experientiam quasi legitimae cuiusdam intemperantiae signum esse credentes.

Those women who had been content with one marriage used to be honoured with a crown of pudicitia; for our ancestors considered that the mind of a matrona was particularly uncorrupted, with the bond of fidelity unbroken, when it did not know how to leave the bed on which her virginity had been laid down, believing that the experience of multiple marriages was a sign of more or less legalised intemperance (Val. Max. 2.I.3).

This honour, in the visible form of a crown of pudicitia given to women who marry only once, once again associates pudicitia with a single marriage. It suggests, more explicitly than the proscriptions on participants in the cult

${ }^{72}$ For the term sanctitas see Introduction, p. 30 above.

73 In the Greek historian Diodorus Siculus' account of Cybele's induction (34/35.32.3) the role is taken by the best of men and the best of women together: the woman in this case is named as Valeria. There is no mention in this account of sexual virtue in particular.

74 See also Cic. Har. resp. 27: 'Urged by this same prophetess [the Sibyl], once upon a time, when Italy was worn out by the Punic War and harassed by Hannibal, our ancestors received these rites from Phrygia and brought them to Rome. The man who welcomed them, P. Scipio, was judged the best [optimus] of all the Roman people, and the woman, Claudia Quinta, was thought the most chaste [castissima] of the matrons; your own sister is held to have imitated her ancient austerity most admirably.' The passage is addressed to Clodius, and ends with a sarcastic reference to his sister Clodia. For more on this family's association with pudicitia and impudicitia see further Chapter 6 below, pp. 298-305. 
of pudicitia itself, that it is the state of being univira - once-married - that provides evidence of a woman's possession of the quality of pudicitia. What is more, Valerius does expand upon the reasons for this honour and the value of being an univira, as he lays out in his long coda his version of antique attitudes.

We must read this passage cautiously (the implications of this will be more fully explored in Chapter 3). Firstly, in this second volume of his work, Valerius is playing the antiquarian, the moral archaeologist, turning up for readers of his own day the traditions and moral outlook of old. As in the case of cult, we must not make the mistake of assuming that this is a straightforward description of Roman practice. Indeed a plausible suggestion has been made that this passage in Valerius represents a confusion on his part, where he has mistaken the traditional crowning of the cult statue with an honorific ritual in which crowns are bestowed on women. ${ }^{75}$ In addition we may note that Valerius feels a need to explain the custom to his readers, as though its significance would not be immediately transparent in the first century CE either. The passage represents the depiction and interpretation of a past that may never have existed, but is felt to be in some way significant in Valerius' present. It is no straightforward description either of the mores of Valerius' own day or of the ancestral mores; rather, the passage is a creative interaction between conceptions of both, that invokes the familiar notions of competition and public honour and the superior virtues of the past.

Just as in Livy's account of the founding of the plebeian cult of pudicitia Verginia appeals to the fact that she came to her husband's bed as a virgin, so Valerius Maximus represents the loss of virginity as a key concern of the ancients in determining pudicitia. The sign of a woman's pudicitia is her commitment to the bed itself in which her virginity was lost and her sexual life first developed, even when that bed can no longer provide her with sex (after her husband is dead). The marital bed as a physical representation of the marriage itself is a notion deeply engrained in ancient cultures. The best-known and paradigmatic depiction of this in literature is the bed of Penelope and Odysseus in Homer's Odyssey, which is fashioned from a living tree and eventually provides the key to their reconciliation. ${ }^{76}$

Valerius' passage suggests that a girl's first sexual experience, through which a change is effected in her that can never be undone or repeated, should bind her in a particularly strong and admirable bond with her sexual

75 Böels-Janssen 1996: 53. On Valerius Maximus see further Chapter 3 below.

${ }^{76} \mathrm{Od}$. 23.177-232. For the marriage bed as symbol of the erotic experience within marriage see Kaimio 2002. 
partner and the bed where it took place. ${ }^{77}$ The admiration he elsewhere expresses for the conduct of the married couple Antonia and Drusus, who are the protagonists of another paradigmatic Roman moral tale, underlines this. The first part of the story repeats the tradition that the glorious Drusus Germanicus 'confined his sex life to his wife's embrace alone' (constitit usum veneris intra coniugis caritatem clausum tenuisse); his constancy is repaid when after his early death his eligible young widow chooses to remain faithful to his memory and never to remarry:

Antonia quoque, femina laudibus virilem familiae suae claritatem supergressa, amorem mariti egregia fide pensavit; quae post eius excessum, forma et aetate florens, convictum socrus pro coniugio habuit, in eodemque toro alterius adulescentiae vigor exstinctus est, alterius viduitatis experientia consenuit.

Antonia too, a woman who surpassed in praise the fame of the male members of her family, balanced the love of her husband with her exceptional commitment to him. After his death, though she was in the flower of her youth and beauty, she continued to live with her mother-in-law rather than with a new husband. In the very same marriage bed where was extinguished the vigour of Drusus' adolescence, grew old the trials of widowhood (Val. Max. 4.3.3).

Antonia's refusal to countenance a second husband is described here as exceptional - as is the fact that Drusus has sex with no one except his wife. The implication is that most young widows would be expected to remarry; Antonia's, then, is an extreme manifestation of commitment to one's spouse (indeed in contrast Tiberius, to whom this work is addressed, had already been conceived by his mother's previous husband when she remarried). Whether her story too is intended to stand as an exemplum of sexual continence is unclear. That is the theme of Valerius' chapter, certainly (it will be discussed in more detail in Chapter 3 below), and we are clearly meant to read Drusus' behaviour as embodying the strength of mind to resist other sexual temptations to which most men would succumb. Antonia's response may be read rather as a digression - perhaps even an indication of the rewards that such behaviour on the part of a husband might reap in terms of wifely fidelity. However, there must be more than a suggestion that in refraining from remarriage Antonia is depriving herself of an erotic life, that she too might be tempted by the promise of (legitimate) sexual activity, but has the strength of mind to pass it by.

Compare Fanny Hill's sadness at leaving the inn where she had lost her virginity to her lover: 'I cannot say but I left with regret, as it was infinitely endeared to me by the first possession of my Charles and the circumstances of losing there that jewel which can never be twice lost.' (John Cleland, Fanny Hill or Memoirs of a Woman of Pleasure (1748), in the Oxford World Classics edition of 1985: 70). Although she has already been sexually 'broken in' by a madam and is destined to become a whore and a courtesan, this passage exposes Fanny's innate virtue and is designed to remind us of the faithful wife to Charles that she might have been had circumstances allowed. 
A passage from Tacitus' Germania where he discusses the effects of the German custom of virgin marriage may offer us further insight into the importance of the first sexual experience of a girl:

melius quidem adhuc eae civitates, in quibus tantum virgines nubunt et cum spe votoque uxoris semel transigitur. sic unum accipiunt maritum quo modo unum corpus unamque vitam, ne ulla cogitatio ultra, ne longior cupiditas, ne tamquam maritum sed tamquam matrimonium ament.

It is even better in those states where all brides are virgins, and the wife's hopes and prayers are dispatched with once and for all. Then they accept one husband just as they accept one body and one life, so that they may think of nothing beyond this, and have no further desire, and may love not so much their husband as marriage itself (Tac. Germ. 19.2). ${ }^{78}$

As an inexperienced virgin, a new wife has no comparative experience of other men that might be brought to bear on her expectations of this marriage, no ambitions for herself beyond this one relationship. When no alternatives are conceived of, the bond to her husband and to the marriage is the surer.

All this - the preservation of the marital bond, the restriction to the marital bed even after death - makes perfect sense as a sign of pudicitia governing a married woman. Yet it is troubling that in these circumstances the virtue can only ever be made manifest when its importance is no longer paramount: after the actual living marriage has been ended by the death of the husband. ${ }^{79}$ After he has died, a wife's refusal to leave her husband's bed or to contemplate embarking on a relationship with a new man may certainly be read as a testament to her commitment to her only marriage (especially when she is young and beautiful and in demand), but this is only possible in retrospect. So how can a man tell whether his wife is committed to their relationship while he is still alive? None of our texts suggests that a woman may only be counted among the univirae once she is a widow, nor that she cannot be considered pudica until after her husband's death. There must therefore (and inevitably) be other ways of judging pudicitia, and perhaps other reasons for labelling a married woman univira.

We need then to apply more pressure to this idea of pudicitia as 'manifest', as enshrined in the cult's requirement that those who tend it should be of spectata pudicitia.

${ }^{78}$ See Chapter 7 below (pp. 32I-9) for a full discussion of this passage and its relevance to Roman sexual mores.

79 In addition, in a culture with such a high death rate among both spouses and children, the decision of a still fertile widow not to remarry comes at a considerable demographic cost. For the argument that despite the idealisation of the univira state remarriage was the norm see Bradley 199r: I56-76. 


\section{APPEARANCE AND REALITY}

A strand in the story of Cybele's introduction to Rome that emerges only in the late first century BCE (notably in the works of Livy, Propertius and Ovid $)^{80}$ highlights the difficulties involved in reading the signs of pudicitia. This is the version of the tale that has Claudia Quinta acquire an unjustly sullied reputation in the eyes of the community and eventually prove her pudicitia through her role in welcoming the goddess into Rome (Pliny's 'trial of religion' is an allusion to this feature of the tradition) ${ }^{81}$ Into the story are introduced the notions of the importance of fama and the idea of deceptive appearances that complicate matters considerably, and raise some of the issues at the heart of Roman pudicitia. ${ }^{82}$ Livy's account does not dwell on this aspect of the narrative, but he does mention it briefly:

matronae primores civitatis, inter quas unius Claudiae Quintae insigne est nomen, accepere; cui dubia, ut traditur, antea fama clariorem ad posteros tam religioso ministerio pudicitiam fecit.

The foremost matronae of the community received the goddess; among them Claudia Quinta is the only one whose name is famous. It is said that her reputation had been until then dubious, but through such a pleasing service to the gods it rendered her pudicitia more illustrious among generations to come (Livy 29.I4.I2).

Livy's manner of reference alerts us to the complexities of an evolving tradition. ${ }^{83}$ This is however portrayed as a key moment in Rome's history, ${ }^{84}$ and one that is once again associated with a woman's publicly acknowledged excellence in pudicitia, which wins her a lasting and illustrious reputation. In this version, Claudia Quinta begins the story with a dubia fama-dubious reputation - and it is the role she plays in the cult's reception that proves

${ }^{80}$ Livy 29.I4, Prop. 4.II.5I-2, Ov. Fast. 4.305-48.

${ }^{81}$ Earlier references to the tale can also be found in Cic. Har. resp. 27; Cael. 34; Fin. 5.64. Later imperial and Christian sources are Sen. fr. 8o (de matrimonio); Plin. Nat. 7.120; Stat. Silv. I.2.245-6; Sil. 17.I-45; Suet. Tib. 2.3; De vir. ill. 44.46; August. De civ. D. 2.5. See Fantham 1998 and Wiseman I979: 94-9 on possible family politics in shaping the tale.

${ }^{82}$ Like so many Roman foundation tales, this story about the vindication of her sexual purity was visibly inscribed on the face of the Roman city in the form of a statue of Claudia Quinta set up in the entrance to the temple of Mater Matuta, to which Valerius Maximus makes reference (Val. Max. I.8.II). The statue is said to have survived two outbreaks of fire that destroyed the building that housed it. The fires are dated by Valerius to III BCE and 3 CE, the latter sufficiently close to his own time (perhaps twenty-odd years prior to publication of his work) to suggest that the temple and statue were still then a significant part of the material of the city, and the narrative part of the city's memory. Wiseman 2000 suggests that the story formed the plot of a play.

$8_{3}$ For instance, the mention of Claudia Quinta's role in the reception of the statue here sounds somewhat grudging, as if the names of the other matronae involved would have been worthy of remembrance too.

$8_{4}$ Levene 1993: 70. 
to the community she is after all utterly pure. This general doubt and then public proof of pudicitia, a recurrent narrative theme of the Roman sources from the late first century $\mathrm{BCE}$, underlines the precariousness of pudicitia, and also, as we shall see, serves to enact certain issues central to Roman ethics: anxieties about how pudicitia can be recognised, how we can know anything about the secret sexual morals of another human being.

The descriptions of the cults both of Venus Verticordia and of Cybele in Ovid's Fasti develop these themes of reputation, misreading and visuality in a complex portrayal of the relationships between pudicitia and fama (reputation or rumour). ${ }^{85}$ As Fantham comments, these women's cults provide good elegiac material for the poet. ${ }^{86}$ The cults are treated in Book 4 of the Fasti, which is devoted to the month of April and dominated by the figure of the goddess Venus to whom the month is sacred. The first reference is to the establishment of the cult of Venus Verticordia:

supplicibus verbis illam placate: sub illa et forma et mores et bona fama manet.

Roma pudicitia proavorum tempore lapsa est:

Cumaeam, veteres, consuluistis anum.

templa iubet fieri Veneri: quibus ordine factis

inde Venus verso nomina corde tenet.

semper ad Aeneadas placido, pulcherrima, vultu

respice, totque tuas, diva, tuere nurus.

Placate her with suppliant words: beneath her power

Beauty and morals and good reputation are all preserved.

At Rome in the times of our ancestors, pudicitia slipped:

You ancients consulted the aged Sibyl of Cumae.

She ordered that there should be temples for Venus: when these had been made appropriately

Then Venus, having turned her heart, took on her epithet. ${ }^{87}$

Most beautiful goddess, always look upon the descendants of Aeneas with a gentle expression,

And guard over your many daughters-in-law (Ov. Fast. 4.I55-62).

As we have seen, the consecration of the temples to the goddess Venus and the new incarnation of her as Verticordia was a national response to a moral crisis when pudicitia failed to hold sway over the Roman people.

85 For more on fama, see Chapter 4 below, pp. 198-9. On Fasti Book 4 see Fantham 1998, and on this passage Porte 1984; on interpretative issues see Herbert-Brown 2002, Feeney 1998: 123-7 on 'The reality of Ovid's Fasti'; also Scheid 1992a, Beard 1987 and Phillips 1992.

${ }^{86}$ Fantham 2002: 24. On Ovid's Fasti as a source for Roman religion see also Beard, North and Price I998 vol. I: $6-7$.

87 In other words, in Ovid's account, it is Venus' change of heart that the epithet Verticordia signals, rather than that of Roman women; cf. n. 66 above. 
Like Valerius Maximus, ${ }^{88}$ Ovid presents her role as watching and guarding, specifically over newly married women. ${ }^{89}$ The three aspects of women's lives that she protects are catalogued in line 156 as their appearance or beauty (forma), their conduct or morality (mores) and their good reputation (bona fama). ${ }^{90}$ The relationship between these three elements is highly problematic, as the following account of Claudia Quinta's story indicates, and we shall see both in the conclusion to this chapter and throughout the rest of this book that there are tensions between the elements of beauty, sexual attraction, morality and standing in the eyes of the community that converge here in the figure and remit of this goddess. Meanwhile the aetiology of this cult, with its mention of the lapse in pudicitia, is a warning of the ease with which the quality can slip away.

I5O lines later begins the treatment of the cult of Cybele, in which Ovid gives a long account of how the cult came to be imported into Rome, with extensive reference to the role of Claudia Quinta (Ovid Fast. 4.305-48). This Claudia is a woman of beauty and high birth and her morals are impeccable - but in terms of the third category of Venus Verticordia's role, fama, she is not so fortunate: her reputation has been damaged by evil rumour:

Claudia Quinta genus Clauso referebat ab alto nec facies impar nobilitate fuit,

casta quidem, sed non et credita est: rumor iniquus laeserat, et falsi criminis acta rea est.

cultus et ornatis varie prodisse capillis obfuit ad rigidos promptaque lingua senes.

conscia mens recti famae mendacia risit, sed nos in vitium credula turba sumus.

Claudia Quinta came from the great Clausus family, And she was as beautiful as she was noble, And pure (casta) too, but this last was not believed: an evil rumour Had damaged her, and she had to defend herself against false accusation. Her manner of dress, the way she went about with her hair all done up in various ways, And her ready tongue prejudiced stern old men against her. Her mind, conscious of right, laughed at the lies of her reputation; But we are a crowd who believe easily in vice (Fast. 4.305-12).

88 Val. Max. 6.I.praef.; see pp. 39-4I above.

s9 The primary meaning of nurus is 'daughter-in-law' though it can be used to denote newly married women. As wives of the descendants of Aeneas all Roman brides are the daughters-in-law of Venus.

${ }^{90}$ It is not entirely clear from the context to which manifestation of Venus this line refers; see Fantham 1998 ad loc. and Fantham 2002 where she suggests that confusion is part of Ovid's elegiac' game. 
Scholars have seen poignancy in this theme of the damage that can be wrought by false accusation and rumour; there are parallels both with Ovid's own exile and with the banishment for adultery of Augustus' daughter Julia. ${ }^{9 \mathrm{I}}$ The emphasis is on the harmful potential of an overvigilant community that misreads the personal signs of one of its members. In Claudia Quinta's case there is a discrepancy between what is generally believed and the truth about this woman, who looks as if she is not casta, because of the way she dresses and does her hair and makes conversation, even though she is and knows it. ${ }^{2}$. Such a discrepancy opens up a disturbing gap between seeming and being that throws the Roman insistence on outward visual display of pudicitia into a predicament. She may laugh in the face of it, but Claudia's impassioned plea to Cybele suggests something other than amusement. She is fortunate; history provides her with the opportunity to slice through the misapprehension of her fellow citizens with divine and unanswerable proof of her virtue. When the combined efforts of the leading citizens prove insufficient to shift the ship carrying the goddess' image from the sands of the Tiber where it is grounded, she steps forward and supplicates Cybele, asking that the goddess confirm her averred virtue by allowing her statue to follow only Claudia:

'supplicis, alma, tuae, genetrix fecunda deorum, accipe sub certa condicione preces.

casta negor: si tu damnas, meruisse fatebor; morte luam poenas iudice victa dea;

sed si crimen abest, tu nostrae pignora vitae re dabis, et castas casta sequere manus.'

dixit et exiguo funem conamine traxit ...

'Accept the prayers of your suppliant, gentle, fecund begetter of the gods, on certain condition.

It is claimed that I am not chaste: if you condemn me, I shall admit that this was deserved;

Defeated, with the goddess as judge, I shall expiate the penalty with my death.

But if there is no crime, you shall grant the pledge of my life In your action, and chaste you will follow chaste hands.'

She spoke and drew the boat with the slightest effort ... (Fast. 4.319-25).

The castitas that was not visible in the person of Claudia herself is made manifest in the miracle of the goddess allowing Claudia to lead her image

91 See Fantham 1998: 155-6.

92 At line 316 the onlookers believe that she has lost her mind (mens), whereas we have been told at line 3II that she has a mens conscious of its own righteousness. 
into Rome. After the celebrations that follow, we return to Claudia, and although throughout the passage so far the quality in question has been castitas, in the concluding lines pudicitia is mentioned specifically:

Claudia praecedit laeto celeberrima vultu, credita vix tandem teste pudica dea;

Claudia went forth with a happy face, highly celebrated

Finally believed to be pudica on the testimony of a goddess (Fast. 4.343-4).

Claudia's misleading appearance invites other Romans to come to the wrong conclusions about her, and it takes a divine miracle to set them straight. Claudia is finally believed, but what hope would she have had without the intervention of Cybele? The story might be read as admonishing women to maintain their outward appearance so as to convey impeccable pudicitia - no laughing, no fancy hairstyles - although it also offers a more comforting illustration of virtue eventually rewarded and recognised. However, it also admonishes readers, as spectators of others, not to jump too easily to conclusions about their morality, and thereby reflects problems raised by Roman culture's demand that pudicitia must be displayed.

\section{SPECTATA PUDICITIA}

A Roman woman should wear her pudicitia on her sleeve for the whole community to see. Indeed a satirical novel from the first century relates a tale in which people literally come from miles around to witness for themselves the exceptional pudicitia of a widow. ${ }^{93}$ But what would such people have come to see? What does pudicitia look like? Livy does not describe to us the visual markers or the behaviour or actions that might have served to distinguish a woman as worthy to participate in the celebration of the cult; perhaps even to explicate what might count as signs of pudicitia would be to profane it. Neither does Petronius give us any hint of what the tourists might have seen in the widow of Ephesus. One catches more frequently glimpses of how the absence of pudicitia might be recognised.

Later representations of pudicitia on imperial coinage of the second and third centuries CE typically show a female figure wearing a stola and with hand raised and frozen in the act of drawing a veil across the face. ${ }^{94}$ A first

93 I.e. the tale of the widow of Ephesus told in Petr. Sat. IIO-I3, a text which will be discussed more fully in Chapter 4 in the context of subversive genres.

94 On the veil gesture in ancient Roman art and its relationship with pudicitia see Myerowitz 1995 , esp. II5 n. 46, North 1966: 308, Llewellyn-Jones 2003: 172; cf. Paus. 3.20.10-1I associating veiling with aidos. 
century CE altar from Rome depicts Claudia Quinta pulling in the boat wearing the matron's stola and with her hair covered, though her face is not veiled. ${ }^{95}$ However, depictions of Claudia Quinta inevitably pose the familiar problem: how do you depict visually a woman who is a paragon of pudicitia, when part of the point of her story is that she didn't look as if she was?

In Ovid's version of her tale, the signs by which the community of Rome judged Claudia Quinta to be unchaste are her dress, her stylish hair arrangement and her easy manner of talking (Fast. 4.309-310). One might compare Cicero's description of his contemporary Clodia in his courtroom speech in defence of Caelius. According to Cicero's graphic argumentation, the married Clodia shows herself to be a courtesan and not therefore liable to the protection of pudicitia, through many physical signals in which appearance and gesture shade into actual inappropriate behaviour:

si quae non nupta mulier . . . denique ita sese gerat non incessu solum, sed ornatu atque comitatu, non flagrantia oculorum, non libertate sermonum, sed etiam complexu, osculatione, actis, navigatione, conviviis, ut non solum meretrix, sed etiam proterva meretrix procaxque videatur . .96

If finally some woman with no husband conducted herself in such a way that, not only through the way she walked, but in her dress and in the company she kept, not only in the flash of her eyes, or in the freedom of her conversation, but even in her kissing and her exploits and her boat rides and dinner parties, she seemed to be not only a courtesan but a wanton and depraved courtesan ... (Cic. Cael. 49).

An early imperial declamation offers us a description of the way that a model wife should manifest her pudicitia so as to ward off the possible advances of a predator:

matrona, quae esse adversus sollicitatorum lascivias volet, prodeat in tantum ornata, quantum ne immunda sit; habeat comites eius aetatis, qua impudici, si nihil aliud, in verecundiam annorum movendi sint. ferat iacentis in terram oculos. adversus officiosum salutatorem inhumana potius quam inverecunda sit, etiam in necessaria resalutandi vice multo rubore confusa. sic se in verecundiam pigneret, ut neget longe ante impudicitiam suam ore quam verbo. in has servandae integritatis custodias nulla libido inrumpet.

95 See Beard, North and Price 1998, vol. II: 46.

96 See further Chapter 6 below on Cicero's speeches. Cf. supporting evidence of a very different kind of source, the inscription on the tombstone of a wife (from Rome and from the period of the Gracchi) where both her conversation and her posture are praised: $C E 52$ 'with charming conversation and with comely gait' (sermone lepido, tum autem incessu commodo); this description comes in the context of her love for her husband and sons, see Lattimore 1962: 271. 
A matrona who wants to oppose the lust of a seducer, let her come out of the house dressed up only just enough to avoid being scruffy. Let her have friends of such an age that the shameless, if nothing else, should be made to respect their years. Let her keep her eyes down; when people insist on greeting her she should prefer to seem rude rather than immodest. Even when she is returning the greeting of relatives she should be blushing greatly; thus she should pledge herself to verecundia, so that her face should deny impudicitia sooner than her word. No lust should break through these defences guarding her integrity (Sen. Contr. 2.7.3). ${ }^{97}$

This picture is immediately contrasted with that of the kind of dangerous behaviour that is likely to encourage a potential seducer (in argument and vocabulary an echo of Cicero's attack on Clodia above):

prodite mihi fronte in omne lenocinium composita, paulo obscurius quam posita veste nudae, exquisito in omnes facetias sermone, tantum non ultro blandientes, ut quisquis viderit non metuat accedere; deinde miramini, si, cum tot argumentis impudicitiam praesumpserit, cultu, incessu, sermone, facie, aliquis repertus est, qui incurrenti adulterae se non subduceret!

Come forward with an expression composed for every allurement, scarcely more covered up than if you weren't wearing any clothes at all, with your conversation carefully trained in every witticism, only just this side of flirtation, so that anyone who saw you would be unafraid to approach you: then, are we to be amazed that, when she has indicated impudicitia in so many signs - the way she dresses, the way she walks, the way she talks, her appearance - someone is to be found who would not hide away when the adulteress approached him? (Sen. Contr. 2.7.4)..$^{8}$

In an anecdote related by Valerius Maximus (see Introduction, p. II above), a husband repudiates his wife because he finds out that she has been out of the house with her head uncovered and unveiled. To display her beauty before the eyes of other men, he tells her, as a parting shot, is to invite suspicion and accusations. In the same chapter another man divorces his wife because she has been seen in public speaking with an unsuitable woman, and another because she has gone to watch the public games without his permission. ${ }^{99}$ These are extreme statements of the same principle: that the way that married women dress and behave in public is grounds for making valid decisions about their moral standing. A woman must not look as if she has beautified herself, or is in any way attempting to attract attention to herself. ${ }^{100}$ She must go so far as to rebuff any offers of social interaction, and must certainly not be forward in conversation.

97 For more on declamation and this text in particular, see Chapter 5 below.

98 Compare too Sallust's depiction of Catiline's associate Sempronia (Sal. Cat. 25).

99 Val. Max. 6.3.IO-I2. For further discussion of these tales in Valerius Maximus see Chapter 3.

100 On the visual codes of female adornment see further Wyke 1994, Myerowitz 1995, Sebesta I998. 
An important way that pudicitia can make itself manifest on her face is through blushing - the Seneca passage almost suggests that this is within the woman's control. ${ }^{\text {ror }}$ The way that a woman presents herself to be seen is naturally important. However, the way that she presents herself as seeing is equally so; a woman who hopes to avert a bad reputation must keep her eyes down and refrain from meeting the gaze of others - her look should not be seen. ${ }^{\text {IO2 }}$ Lucretia, appearing as a shining paragon of pudicitia in Silius Italicus' underworld, is described as having 'her eyes fixed upon the ground'. ${ }^{103}$ Clodia on the other hand has 'blazing eyes' (flagrantia oculorum), according to Cicero's description, that dare to stare right back at men, and these are seen as an invitation for sexual approach.

The visibility of pudicitia relies, then, primarily on external appearance and public social behaviour, and the virtue will turn out to be as much about these as about the sexual behaviour itself. The moral force itself that guides sexual behaviour is elusive and secret. As a means of regulating the behaviour of those into whose souls they cannot see, Roman society has drawn a close conceptual link between the virtue and appearance of an individual. Using a complex visual code to which we no longer have complete access, Romans had ways of reading the virtues of an individual on the body. ${ }^{104}$

The efficient functioning of this system and the reliability of the code are vital for the regulation of sexuality; yet despite this the ancient sources themselves raise concerns about the fallibility of this means of control. Many sources write of the worrying inconsistency between the appearance of virtue and the reality of virtue, and this book argues that this is one of the central anxieties of Roman sexual ethics. We have already seen how in Ovid's Fasti Claudia Quinta, latterly a paragon of pudicitia, was initially held in suspicion by the Roman community on account of her appearance and manners. The familiar code of dress and gait and conversation are read by spectators of the woman so that they may know her moral standing, yet the signs are misread or even deceptive and their significance is misunderstood. This story tells of a gap between what the viewer is led to believe by the public demeanour of a woman and her true virtuous nature. The truth

IoI On blushing see Barton 1999, 2002 and my Introduction, p. I9.

I02 These constraints are not only for married women, as we shall see, especially in Chapters 5 and 6 below. In Val. Max. 6.I.7 the virtue of the (young, male) intended victim and thus the magnitude of the would-be stuprator's crime is brought home to the spectators by the former's demeanour in the courtroom: he says nothing and stares at the floor, thereby demonstrating to all his verecundia.

I03 Sil. 13. 822; see Chapter 2 below, p. 78.

I04 See Corbeill 2004 and Chapters 5 and 6 below, which discuss the way that masculine sexual virtue is written on the body. 
of Claudia's pudicitia can only be revealed by its divine acknowledgment; it is not otherwise available to mortals. Quintilian, too, writes in his rhetorical handbook about the problematics of reading the apparent signs of adultery; addressing precisely the passage from the pro Caelio above, it argues that a woman is not proved to be an adulteress merely because she dines with men and all the rest. ${ }^{\text {Ios }}$ For the Romans, pudicitia remains an elusive quality, which can sometimes be pinned down only by extraordinary (even superhuman) means.

The difficulty of seeing and knowing sexual virtue and integrity is also demonstrated by the story of the Vestal Virgin Tuccia and her sieve. ${ }^{\text {I06 }}$ Although everyone believes her to be lacking castitas, Tuccia calls on Vesta, the goddess she serves, to enable her, if she is truly chaste, to bring water from the Tiber to the temple in a siéve, and so, when the miracle has been achieved, her reputation is cleared, and the charge is dismissed from court. The ritual and symbolic associations of the sieve are relevant here, ${ }^{107}$ yet Valerius tells this story not as part of a chapter on miracles, but as one of a series of courtroom trials that produced out-of-the-ordinary acquittals, emphasising the legal aspects of the case, which suggests that this story is in part a comment on the fallibility of mortal legislation and courtroom procedure. ${ }^{\text {I08 }}$ When a woman is called upon to disprove accusations of sexual impurity not by producing witnesses to attest to her character, not by eloquently persuading the court of her pudicitia, but by carrying water in a sieve - then we see plainly the elusiveness of sexual virtue for the ancient Romans, and we understand how far one must go beyond inquiring about sexual practice itself to be sure of having witnessed it. In these sources, however, the women are always proved to be in reality pudicae; for the even more worrying phenomenon of women seeming pudicae, but in fact not being so, we must wait until the literature of the empire ... (see Chapter 4 below).

THE DANGERS OF DISPLAYING PUDICITIA

I have argued that pudicitia demands to be seen and displayed in public. Yet Sulpicius Galus' wife was divorced for no other reason than that she displayed herself in public in a way that was displeasing to her husband. ${ }^{109}$

${ }_{105}$ Quint. Inst. 5.9.I4. $\quad{ }^{106}$ Val. Max. 8.r.absol.5, Livy Per. 20.

107 See Staples 1997; Carson 1989; Richlin 1997c: 357.

${ }_{108}$ Compare the use of legal terminology in Ovid's Fasti. For more on the fallibility of the legal system see below Chapter 2, p. 97, Chapter 4, p. 204, and Chapter 7, pp. 33I-2.

109 As above, Val. Max. 6.3.IO. I follow Briscoe 1998 in calling him Galus rather than Gallus. 
Women must call attention to their pudicitia but without attracting the sort of attention from other men that might incur censure. These constraints are eminently comprehensible, yet there is a thin line between these different kinds of display; many ancient sources, as this book will show, draw attention to this fact, whether to dwell on its ironies or to express anxieties about the possibility of its breach.

In the second poem of his collection, Propertius tells his puella not to spoil her looks with artifice, and that a girl is most attractive when she is unmade-up and unadorned:

Quid iuvat ornato procedere, vita, capillo

et tenuis Coa veste movere sinus,

aut quid Orontea crinis perfundere murra, teque peregrinis vendere muneribus, naturaeque decus mercato perdere cultu, nec sinere in propriis membra nitere bonis?

crede mihi, non ulla est medicina figurae: nudus amor formae non amat artificem.

What is the point, darling, of going around with your hair all done up, And swinging your soft curves in a Coan dress,

Or pouring Orontean myrrh on your locks, And selling yourself with foreign gifts,

And destroying the ornaments of nature with elegance that you have purchased, And not allowing your body to shine forth with its own attributes?

Believe me, there is no potion for good looks:

Naked love does not love the counterfeiter of beauty (Prop. I.2.I-8).

This plea on behalf of natural beauty is a conventional poetic trope. ${ }^{\text {IIO }}$ Here Propertius follows it with a description of the profusion of beauty in nature, and then alludes to the naive attractions of female figures from Greek myth, whose fate was to be carried off by gods. He comments of these girls:

non illis studium vulgo conquirere amantis;

illis ampla satis forma pudicitia.

They were not eager to conquer lovers at random;

for them pudicitia was ample beauty enough (Prop. I.2.23-4).

In other words, these girls who are abducted by lustful divinities are held up as the moral paradigms for Propertius' addressee. On one level the poem looks like an admonition to the poet's girlfriend or even wife, with 
a traditional moral message about the regulation of the appearance and its association with sexual morality within a (marital) relationship. There is no doubt that the poem makes reference to such ideological aspects. Yet it forms part of a collection and a genre where we are invited to find ironies and play. ${ }^{\text {III }}$ There is considerable irony in this little phrase - 'pudicitia (was or is) beauty enough', which in the Latin (where there is no verb to fix the tense) resounds like a maxim - somewhat similar to the phrase we found in Seneca: 'pudicitia is the greatest ornament'. ${ }^{112}$ Propertius' phrase can be read as a universalising statement: the appearance of the virtue itself is enough to make airl beautiful, and the quality of pudicitia can be a turn-on. And so, paradoxically, when pudicitia is seen as a visual quality that decorates or beautifies its possessor, it also becomes a dangerous attribute that renders sexual integrity insecure. ${ }^{\mathrm{II} 3}$ In the context of the lines in Propertius' poem immediately preceding, pudicitia becomes a tool for attracting men to rape you, rather than the traditional protection against this. ${ }^{\text {II4 }}$

Meanwhile, to add to the confusion, in line 5 of the poem Propertius uses the Latin term decus (a term which has a wide range of meanings in Latin, from honour to visual decoration $)^{\mathrm{II}}$ for the natural physical beauty of the unspoilt girl. If we juxtapose this mischievous verse with the philosopher Seneca's demure praise of his mother (cited at the head of this chapter), we see the Roman dilemma nicely summarised. Seneca describes pudicitia as the maximum decus, which we might translate as 'the greatest ornament/decoration/glory'. The context is a moralising barrage in which he compares his mother to other women who are characterised by the greatest evil of the day: impudicitia.

non te maximum saeculi malum, impudicitia, in numerum plurium adduxit. non gemmae te, non margaritae flexerunt; non tibi divitiae velut maximum generis humani bonum refulserunt; non te, bene in antiqua et severa institutam domo, periculosa etiam probis peiorum detorsit imitatio. numquam te fecunditatis tuae, quasi exprobraret aetatem, puduit, numquam more aliarum, quibus omnis commendatio ex forma petitur, tumescentem uterum abscondisti quasi indecens onus, nec intra viscera tua conceptas spes liberorum elisisti; non faciem coloribus ac lenociniis polluisti; numquam tibi vestis placuit quae nihil amplius nudaret cum

${ }^{I I}$ For more on this see Chapter 4 below. Elegy points up the ambiguities of all aspects of beauty and appearance. Cf. Prop. 3.24.I: 'confidence in your beauty, woman, is misplaced' (falsa est ista tuae, mulier, fiducia formae).

112 See p. 37 above.

${ }^{113}$ For the dangerous and corrupting consequences of being beautiful see e.g. Val. Max. 4.5.ext.I on the Etruscan boy Spurinna, who disfigures himself to avoid the suspicions attached to his allure, or Juv. 10.293-8.

${ }^{11}+$ For more on traditional ideas about pudicitia as protection for unmarried girls see Chapters 2 and 3 below.

-15 See above n. I. There is a similar ambiguiry in the Greek term kosmos. 
poneretur: unicum tibi ornamentum, pulcherrima et nulli obnoxia aetati forma, maximum decus visa est pudicitia.

The greatest evil of our day, impudicitia, has not welcomed you into the masses. No jewels, no pearls have swayed your purpose; for you riches have not shone out as if they were the greatest good of humankind. Brought up as you were in an old-fashioned and strict household, you have not been twisted by the dangerous imitation of people worse than yourself, which is dangerous even to the morally upright. You were never ashamed of your fecundity because it betrays your age, nor, unlike others who value above all things being appreciated for their appearance, did you hide your burgeoning womb as if it were an unsightly burden, or cut out from your insides the child-to-be; you did not pollute your appearance with meretricious make-up; you never liked clothing which is little better than nudity. In you is to be seen the only form of ornamentation, the most lovely kind of beauty which is damaging to no age, the greatest adornment [decus $]$ - pudicitia (Dial. 12.16.2-4).

Just like Propertius, Seneca is making a contrast between the woman in whom one sees pudicitia and the woman who adorns herself with jewels and make-up and expensive clothes in the hope of drawing the admiring glances of men. The passage confirms the moral implications of dressing up that we saw outlined above. In contrast, decus can also mean honour or glory, or decoration in the sense of a public recognition of glory, and so once again we see here pudicitia as the parallel of masculine virtue and glory won on the battlefield. The woman who decorates herself with pudicitia is a woman of the utmost virtue, markedly different from the rest of the female sex. And yet . . in Seneca's phrase pudicitia is figured in itself as a form of decoration in the sense of beauty and ornament, and when it is visible in her person it will lend the virtuous woman a particularly compelling form of beauty.

This dangerous paradox - of pudicitia as a form of beauty that attracts its own destruction - is written into the most famous of all Roman narratives about pudicitia: the story of the wicked Tarquinius who forces the virtuous Lucretia to have sex with him, and of her subsequent suicide. In the following chapter I shall analyse this paradigmatic narrative and show how amongst other things Livy's account is one of those sources that dwell on two of the key issues sparked by the concept of pudicitia: the anxiety about how to recognise or display pudicitia, and the paradoxical dangers of display.

I started this chapter by making bold claims about the cult of pudicitia in Roman culture. In the process of analysing the sources closely I have 
shown that what the sources can provide us with is something far less certain. We cannot know how Romans celebrated the cult of pudicitia or what role it played in the fabric of Roman society. We can access only a series of reflections upon the cult from writers who make explicit claims that they are living in times when the cult is losing or has lost its grip upon society. The texts we have encountered in the course of this chapter do not so much tell us about the cult of pudicitia as use it to talk about moral, social and political issues. In doing so they reveal what the idea of the cult means to them, or means in the specific context in which they were writing. Sometimes this significance is revealed self-consciously and deliberately, at others it may be found in underlying structures or assumptions of the text owing to the personal, cultural or historical background in which the author writes, of which he is not himself necessarily aware. ${ }^{\mathrm{II}}{ }^{\mathrm{m}}$

The various preoccupations of the texts that I have here used as sources will emerge in the course of the following chapters, where a range of works are examined in turn with reference to the literary and historical contexts that shaped them. However, we can already see in these texts certain themes that emerge regarding pudicitia. Display is undoubtedly important to pudicitia, despite the complexity of the relationship between the two. The sources portray the cult as having significance in mediating between the individual and the morals of the community. They also make assumptions about the relationship between instances of wrongful sexual behaviour of individuals and the welfare of the whole state that serve to heighten the sense that it is vital to regulate one's behaviour. The themes of women's ethics, national stability, visibility, public display, reputation, and competition all appear again and again in various relations to one another throughout these sources.

II6 Compare Umberto Eco's reflection on the contemporary interpreters of his own work in Eco 1992. 